\title{
Eccentric Exercise Decrease Blood Glucose Level and Improve Protein Level of Glucose Transporters in Diabetic Mice Muscle
}

\author{
Handoko Adelia ${ }^{1}$, Purwanto Bambang ${ }^{2}$, Mustika Arifa ${ }^{3}$ \\ ${ }^{1}$ Staff of Department of Physiology, Faculty of Medicine, University of Jember, Kalimantan 37 Kampus Tegal \\ Boto, Jember 68121; ' 2 Staff of Department of Physiology, Faculty of Medicine, Universitas Airlangga, Surabaya, \\ Indonesia, Jl. Mayjen Prof. Dr. Moestopo No.47, Pacar Kembang, Kec. Tambaksari, Kota Surabaya, Jawa Timur \\ 60132, '3taff Department of Pharmacology, Faculty of Medicine, Universitas Airlangga, SurabayaSurabaya, \\ Indonesia, Jl. Mayjen Prof. Dr. Moestopo No.47, Pacar Kembang, Kec. Tambaksari, Kota Surabaya, Jawa Timur \\ 60132
}

\begin{abstract}
Background: Previously, eccentric exercise improved on blood glucose level better than concentric and isometric exercise. The improvement of blood glucose level was resulted from higher glucose uptake activity, particularly at the muscles. Unfortunately here isn't yet information whether it is facilitated by glucose transporter type 1 or glucose transporter type 4 .

Objectives: The aim of the present study was to investigate the effect of eccentric activity on glucose transporter type 1 and glucose transporter type 4 in gastrocnemius muscle of streptozotocin-induced diabetes mellitus mice.

Methods: Diabetic mice were grouped randomly into 4 groups ( 7 mice each group). Two groups were observed during fasting and others were observed during post prandial. Single bout of eccentric activity was given by downhill running on $10 \mathrm{o}$ degree decline treadmill. The protein level of glucose transporters were measured using monoclonal antibody in ELISA protocol. Blood glucose level was measured on fasting and post prandial using colorimetric protocol of EASY TOUCH app.
\end{abstract}

Result: Glucose levels (fasting and post prandial) of eccentric group were significantly lower than isometric group. Consistently, protein level of glucose transporters (type 1 and type 4) were significantly higher than isometric group. Type-4 glucose transporter level was higher than type-1 glucose transporter, found in calf muscle.

Conclusions: single bout of eccentric exercise on downhill running improve blood glucose level due to both GLUT-1 and GLUT-4 protein levels improvement.

Keyword: exercise, glucose transporter, diabetes mellitus, streptozotocin, muscle

\section{Background}

Diabetes mellitus (DM) is a metabolic disorder

\section{Corresponding author:}

\section{Handoko Adelia:}

Staff of Department of Physiology, Faculty of

Medicine, University of Jember, Kalimantan 37

Kampus Tegal Boto, Jember 68121;

adelia.fk@unej.ac.id characterized by hyperglycemia. The International Diabetes Federation (IDF) (2015) estimates that patients with DM will increase from 415 million in 2015 to 642 million by 2040, while in Indonesia it is estimated at about 21.3 million people by 2025 . Type 2 diabetes mellitus affects $90-95 \%$ of total diabetics. Type 2 diabetes mellitus is caused by inadequate insulin secretion (insulin deficiency) and/or lack of tissue sensitivity to insulin (insulin resistance) ${ }^{(1,2)}$. 
Insulin work involves the process of signaling insulin towards a glucose transporter (GLUT). GLUT1 and GLUT-4 are group of transmembrane glucose transporter family proteins that facilitate glucose uptake. The decrease in GLUT-1 and GLUT-4 found in DM affects glucose uptake disruption, therefore, it results in an increase in basal and postprandial blood glucose $\mathrm{e}^{(3,4)}$. As of recently, various innovative approaches have been conducted to address and prevent DM. In the last three decades, the study of exercise for DM management has laid several alternatives. The American Diabetes Association recommends continuously aerobic exercise to prevent DM. Other studies on High Intensity Interval Training (HIIT) and eccentric exercises show an effect on improving fasting glucose and postprandial glucose level in normal mice as well as in diabetic mice compared with isometric and concentric ${ }^{(5)}$.

Marcus's study suggests that eccentric contractionbased exercises can provide benefits compared to the only use of aerobic exercise. Research by Heled reveals treadmill exercises without angle adjustment for 4 weeks with 2 times a week frequency and 90 minutes duration effect on increased in levels of GLUT-1 ${ }^{(6,7)}$. Increased in levels of GLUT-1 occur shortly after eccentric activity in normal mice ${ }^{(8,9)}$.Eccentric activity affected GLUT-4, it also increased GLUT-4 in normal mice ${ }^{(10)}$.Hence, it is thought to increase the level of GLUT-1 and GLUT-4 but the increased levels of GLUT-1 and GLUT-4 after eccentric exercise have not been explained yet.

Exercise can lower blood glucose rapidly through contracted muscles.Eccentric exercise causes local hypoxia of skeletal muscle tissue; hypoxia is responded by hypoxia inducible factor-1 $\alpha$ (HIF-1 $\alpha$ ) activation. HIF- $1 \alpha$ is increased shortly after defend training up to 6 hours as well as an increase in some mRNA targets ${ }^{(11)}$. In Lundby's study GLUT-1 is the target of the HIF-1 $\alpha$ gene, but the effect of eccentric exercise on mRNA and the GLUT-1 protein has not been known yet ${ }^{(8)}$. The GLUT1 promoter has the HIF-1 binding site needed for GLUT1 activation $^{(9)}$. Increased levels of GLUT-1 can rise intracellular glucose uptake characterized by decreased fasting blood glucose level.Intracellular glucose is the source of ATP used for the phosphorylation cascade of the GLUT-4 signal-transduction pathway and enhances the synthesis of GLUT-4 ${ }^{(12)}$. Lundby also studied that GLUT-4 encountered an increase in hypoxia although GLUT-4 was not a target of the HIF-1 $\alpha$ gen $^{(8)}$.

A common example of eccentric exercise is downhill running ${ }^{(13)}$. The concept of eccentric exercise of downhill running can be conducted with a treadmill as it can be repeatedly done with dynamic angles and consistent speed. On the treadmill, downhill running is performed by giving the declination angle, in this condition, the more dominant muscle contraction is the eccentric contraction ${ }^{(14)}$. The angle used in this study was $10^{0}$.

Appropriate mechanisms and the studies on the effect of eccentric exercise on GLUT-1 and GLUT-4 levels in DM have not been explained yet and it requires further study. Therefore, this study was designed to investigate the effect of eccentric exercise of downhill running with declination angle $10^{0}$ to GLUT-1 and GLUT-4 levels of gastrocnemius muscle of streptozotocin-induced diabetes mellitus mice.

\section{Material and Methods}

This research is conducted by experimental laboratory research with posttest only control group design. The study was divided into 4 groups, namely, K1p group (group of fasting mice, which is given $0^{\circ}$ angle treadmill activity), K2p (group of fasting mice which is given $10^{\circ}$ declination angle treadmill activity), $\mathrm{K} 1 \mathrm{pp}$ (mice group of DM postprandial model which is given $0^{\circ}$ angle treadmill activity, K2pp (mice group of DM postprandial model which is given treadmill activity of $10^{\circ}$ declination angle). All protocols and treatment have been examined through ethical test at Faculty of Veterinary Medicine of Airlangga University. Acclimatization was conducted for 1 week before started the research.

These four groups were induced with streptozotocin with $40 \mathrm{mg} / \mathrm{kg}$ of body weight dose amount for 5 times ( 5 days) intraperitoneally. On 12th day of it, all mice have 
fasting blood sugar level $>180 \mathrm{mg} / \mathrm{dl}$. The next day, the K1p and K1pp groups were subjected to a treadmill activity of $0^{\circ}$ angle at a speed of $20 \mathrm{~cm} / \mathrm{s}$ for 12 minutes (duration was determined by preliminary test). The K2p and $\mathrm{K} 2 \mathrm{pp}$ groups were given treadmill activity of $10^{\circ}$ declination angle at $20 \mathrm{~cm} / \mathrm{s}$ for 12 minutes. Twentyfour hours after the treatment was completed, K1p and $\mathrm{K} 2 \mathrm{p}$ groups were sacrificed for blood collection for sample and gastrocnemius muscle tissue to be examined in fasting glucose level and GLUT-1 muscle level. Forty-eight hours after the treatment was completed, the mice in K1pp and K2pp groups were sacrificed for blood collection for sample and gastrocnemius muscle tissue to be examined in postprandial blood glucose examination with oral glucose tolerance test and GLUT-4 levels of muscle. Blood glucose levels were measured using colorimetric protocols from the Easy Touch glucometer while GLUT-1 and GLUT-4 muscle levels were measured using monoclonal antibody ELISA and total muscle proteins were examined with nanodrops.

\section{Findings}

Data obtained from each research group were then analyzed using independent t-test. The average of fasting blood glucose levels of the treadmill group of $10^{\circ}$ declination angle were $180,86 \mathrm{mg} / \mathrm{dl}$ and the $0^{\circ}$ angle treadmill group was $225,57 \mathrm{mg} / \mathrm{dl}$. The average of blood glucose levels of $10^{\circ}$ treadmill angle postprandial group was $220,14 \mathrm{mg} / \mathrm{dl}$ and group of $0^{\circ}$ angle treadmill was $310,557 \mathrm{mg} / \mathrm{dl}$. The average levels of GLUT-1 treadmill group of $10^{\circ}$ declination angle was $4,04 \mathrm{ng} / \mathrm{mg}$ and the $0^{\circ}$ angle treadmill group was $3.37 \mathrm{ng} / \mathrm{mg}$. The average level of GLUT-4 muscle group treadmill declination angle of $10^{\circ}$ was $5.63 \mathrm{ng} / \mathrm{mg}$ and the treadmill group of $0^{\circ}$ angle was $4.29 \mathrm{ng} / \mathrm{mg}$. Significant results were found in the four parameters of fasting blood glucose, postprandial blood glucose, GLUT-1 muscle level and GLUT-4 muscle level $(0.042,0.033,0.033,0.003)$ as seen in Table 1.

Tabel 1. Results of t-test

\begin{tabular}{|c|c|c|c|}
\hline Parameters & Treadmill & Mean \pm SD & Sig t-test (p) \\
\hline \multirow{2}{*}{ Fasting blood glucose levels (mg/dl) } & 00 angle & $225,57 \pm 50,96$ & \multirow{2}{*}{0,042} \\
\hline & 100 declination angle & $180,86 \pm 41,30$ & \\
\hline \multirow{2}{*}{$\begin{array}{l}\text { Post prandial blood glucose levels } \\
\qquad(\mathrm{mg} / \mathrm{dl})\end{array}$} & 00 angle & $318,71 \pm 89,03$ & \multirow{2}{*}{0,033} \\
\hline & 100 declination angle & $220,14 \pm 61,94$ & \\
\hline \multirow{2}{*}{ GLUT-1 muscle levels (ng/mg) } & 00 angle & $3,27 \pm 0,35$ & \multirow{2}{*}{0,033} \\
\hline & 100 declination angle & $4,04 \pm 0,77$ & \\
\hline \multirow{2}{*}{ Kadar GLUT-4 muscle levels (ng/mg) } & 00 angle & $4,29 \pm 0,59$ & \multirow{2}{*}{0,003} \\
\hline & 100 declination angle & $5,62 \pm 0,76$ & \\
\hline
\end{tabular}




\section{Discussion}

Fasting blood glucose is affected by level of glucose transporter-1 (GLUT-1), particularly glucose transporters located in the muscle, the increased of GLUT-1 leading to a decrease of fasting blood glucose. It is consistent with the results as seen in Table 1. GLUT-1 is commonly present in every undifferentiated cell; it is found in young muscles expressed in basal condition. In diabetes mellitus, GLUT-1 was increased, in this study found a significant enhancement in the declination angle of $10^{\circ}$. Muscle stretches that occur through eccentric contractions caused physical stress and caused ischemic reperfusion stress, repeatedly blood vessels dilation and strictures, affecting turbulence of blood flow and local hypoxia. Hypoxia muscle tissue can induce the Hypoxia-Inducible Factor-1 (HIF-1) ${ }^{(15)}$. In line with Migulez, Lindholm and Rundqvist reveals that hypoxia is responded by activation of hypoxia-sensitive transcription factor hypoxia inducible factor-1 $\alpha$ (HIF$1 \alpha)$. HIF-1 $\alpha$, a major mediator of hypoxia cell is an undetectable transcription factor in normoxia, therefore, it can only be induced in hypoxia. The increase of HIF- $1 \alpha$ is accompanied by an increase in some mRNA targets ${ }^{(8)}$. The regulation of GLUT-1 mRNA was mediated by HIF-1, so the activation of HIF-1 $\alpha$ leads to increased synthesis of GLUT-1 levels, hence, GLUT-1 expression on the plasma membrane were also increase ${ }^{(3)}$.

Fasting blood glucose levels were lower in the group given treadmill treatment with $10^{\circ}$ declination angle than in the group given treadmill activity treatment with angle $0^{\circ}$. This result is in line with Fujishiro's study, that the increased GLUT-1 is accompanied by decreased fasting blood glucose, GLUT-1 provides glucose for cells at basal condition ${ }^{(16)}$. The uptake of glucose level at basal condition is adjusted through a non-insulinmediated glucose uptake mechanism, that is $75-85 \%{ }^{(3)}$. The increase of GLUT-1 causes a periodically decreased fasting blood glucose level, reduced in dependency on insulin and improved glucose balance. The increase of GLUT-1 causes increased glucose uptake into cells to be used in glycolysis reaction that produce energy thereby it reduced fasting blood glucose level ${ }^{(17)}$. The eccentric activity of downhill running for a single session of $10^{\circ}$ declination angle is sufficient to facilitate ischemic reperfusion stress and local hypoxia events, so, it results a significant decrease in fasting blood glucose levels ${ }^{(18)}$.

In this study, it is conducted a measurement of fasting blood glucose levels and GLUT-1 levels of muscle 24 hours after treatment based on Forsyte research in which Vascular Endothelial Growth Factor (VEGF) and erythropoietin (EPO) were also the HIF$1 \alpha$ target genes, the study showed that the hypoxia condition caused increased VEGF and EPO within 24 hours and the study by Hayashi showed that in hypoxic condition there was an increased GLUT-1 through HIF$1 \alpha$ within 24 hours, the peak time of HIF-1 $\alpha$ content has not been known yet, so it is required serial measurement of HIF-1 $\alpha$ levels ${ }^{(19,20)}$

Based on the analysis that has been performed, there is a difference of average level of GLUT-4 muscle between $0^{\circ}$ and $10^{\circ}$ angle treadmill group. GLUT-4 is one of the glucose transporters that responsible for controlling postprandial blood glucose, synthesis and translocation of GLUT-4 through various phosphorylation cascades that require a lot of ATP. Intracellular glucose is the source of ATP used for the phosphorylation cascade of the GLUT-4 signal-transduction pathway and enhances the synthesis of GLUT-4 ${ }^{(12)}$. This study proves that higher GLUT-4 levels in the group given treadmill activity with $10^{\circ}$ declination angle signifies the adequacy of ATP in the muscle compared to the group given treadmill activity with $0^{\circ}$ declination angle.

Insulin binds with the receptor and initiates the PI3K signal pathway in sarcolemma about 1-2 minutes after insulin entry. Insulin binds to the Insulin Receptor (IR), insulin binds to the $\alpha$ subunit receptor located at the extracellular and causes the ATP bond in the $\beta$ subunit component in intracellular through the tyrosine kinase enzyme. The phosphorylation of tyrosine on these intracellular substrates referred to IRS (Insulin Receptor Substrate), will then bind with the scrhomology-2 (SH2) protein domain causing activation of phosphatidylinositol-3 kinase (PI3K). This complex 
condition will activate phosphoinositide dependent protein kinase (PDK-1 and PDK-2) and causing activation of protein kinase $\mathrm{B}(\mathrm{PKB}) / \mathrm{Akt}$ and protein kinase $\mathrm{C}$ (PKC) through serine and threonine kinase. The activation of Akt will phosphorylate 160kDa (AS160) Akt substrate. Akt and AS 160 are signals that cause glucose translocation from extracellular to intracellular by glucose transporters. The total duration required to activate PI3K is 20 minutes after the entry of insulin in white muscle, PI3K will progressively activate and peak for 10 minutes. The translocation of GLUT-4 into the cell membrane through the mechanism of acute insulindependent glucose uptake has a major role in controlling postprandial blood glucose ${ }^{(21)}$.

\section{Conclusion}

The conclusion is theeccentric momentarily downhill running activity with $10^{\circ}$ angle increases the levels of GLUT-1 and GLUT-4 muscles and reduces fasting blood glucose and postprandial blood glucose levels.

Conflict of Interest: The authors declare that there is no conflict of interest for this research.

Acknowledgments: We would like to thank all the members of staff at Airlangga University who helped us during the research.

Source of Funding: The authors received financial support for the research from BPPDN.

\section{References}

1. International Diabetes Federation. About Diabetes - Facts and Figure (2015)

2. SuyonoS : Diabetes Melitus di Indonesia. Dalam Sudoyo, Setiyohadi, Alwi, Simadibrata, Setiati (Editor). Buku Ajar Ilmu Penyakit Dalam Jilid III Edisi IV. Departemen Ilmu Penyakit Dalam Fakultas Kedokteran Universitas Indonesia, Jakarta (2006)

3. Ciaraldi TP, MaudaliarS, BarzinA. Skletal muscle GLUT-1 transporter protein expression and basal leg glucose uptake are reduced in type 2 diabetes, Journal of Clinical Endocrinology and metabolism; Vol 90: pp.352-358 (2007)
4. Sulistyoningrum E. Tinjauan Molekular daan Aspek Klinis Resistensi Insulin, Mandala of Health; Vol. 4: pp. 131-138 (2010)

5. PittasAG, Hughes BD. Vitamin D and diabetes, Journal of steroid Biochemistry and Molecular Biology; Vol. 121: pp. 425-429 (2010)

6. Marcus RL, Smith S, Morrel G.Comparison of combined aerobic and high force eccentric resistance exercise with aerobic exercise only for people with type 2 diabetes melitus. Journal of the American Physical Therapy Association; Vol.88(11): pp. 1345-1354 (2008.)

7. Heled Y, Dror Y, Moran DS. Physical exercise increases the expression of TNFa and GLUT 1 in muscle tissue of diabetes prone Psammomys obesus, Life Sciences; Vol. 77: pp. 2977-2985 (2005)

8. Lundby C, Calbet JAL, Robach P. The response of human skeletal muscle tissue to hypoxia, Cell. Mol. Life Sci; Vol. 66: pp. 3615-3623 (2009)

9. Purwantini D.Pengaruh Latihan Eksentrik Sesi Tunggal pada Sudut Deklinasi $-5^{\circ},-10^{\circ}$, dan $-15^{\circ}$ terhadap Peningkatan Ekspresi GLUT-1 Otot Gastrocnemius Mencit. Fakultas Kedokteran Universitas Airlangga (2014)

10. Pora YD. Pengaruh latihan eksentrik sesaat (lari downhill) pada sudut deklinasi $-5^{0},-10^{0}$ dan $-15^{0}$ terhadap penurunan kadar GLUT-4 pada otot gastroknemius mencit (mus musculus). Fakultas Kedokteran Universitas Airlangga (2014)

11. Lindholm ME, Rundqvist $H$. Skletal muscle hypoxia-inducible factor-1 and exercise, Exp Physiol; Vol. 101(1): pp. 28-32 (2016)

12. Ghani MA, De Fronzo RA. Pathogenesis of insulin resistance in skletal muscle, Journal of Biomedicine of Biotechnology; Vol. 2010 (2009)

13. Whitehead NP, Allen TJ, MorganDL, Proske U. Damage to human mus- cle from eccentric exercise after training with concentric exercise. J Physiol 512: pp. 615- 620 (1998)

14. DrexelH, Saely CH, Langer P. Metabolic and anti-inflammatory benefits of eccentric endurance exercise - a pilot study, Eur J Clin Invest; Vol. 38: pp.218-226 (2008)

15. Miguelez, PR,Cabello EL. Hypoxia-inducible factor-1 modulates the expression of vascular endothelial growth factor and endothelial nitric oxide synthase induced by eccentric exercise. $\mathrm{J}$ 
170 Medico-legal Update, October-December 2021, Vol.21, No. 4

Appl Physiol 118: pp. 1075-1083 (2015)

16. FujishiroM, Gotoh Y, Katagiri H.MKK3/6 and P38 MAPK pathway activation is not necessary for insulin induced glucose uptake but regulates glucose transporter expression, The Journal of Biological Chemistry; Vol. 276: pp. 19800-19806 (2001)

17. Purwanto, B. Kontraksi eksentrik: Respon fisiologis otot mencegah kerusakan. PT Revka Petra Medika, Surabaya (2016)

18. KusumaH, Abdullah A, Purwanto B. Penambahan besar sudut inklinasi insole sepatu kerja menurunkan kadar glukosa darah puasa dan HbA1c. Jurnal Ners; Vol. 11(1): pp.29-33 (2016)
19. Forsythe JA, Jiang BH, Semenza GL. Activation of Vascular Endothelial Growth Factor Gene Transcription by Hypoxia-Inducible Factor 1, Molecular and Celular Biology Journal; Vol.16(9): pp.4604-4613 (1996)

20. Hayashi M, Sakata M, Takeda, T.Induction of glucose transporter 1 expression through hypoxiainducible factor 1 under hypoxic conditions in trophoblast-derived cells, Journal of Endocrinology; Vol.183: pp. 145-154 (2004)

21. HansL. Insulin and Contraction-induced GLUT-4 Traffic in Muscle:Insights from a Novel Imaging Approach. Exerc Sport Sci Rev. 2013 April ; 41(2): pp. 77-86 (2013) 